\title{
THE FOUR-FACTOR MODEL AND STOCK RETURNS IN BANGLADESH
}

\author{
Dr. Muhammad Saifuddin Khan \\ Associate Professor \\ Department of Finance, Faculty of Business Studies \\ University of Dhaka, Dhaka-1000, Bangladesh \\ E-mail: saifuddin@du.ac.bd \\ Md. Miad Uddin Fahim \\ Postgraduate Student \\ Department of Finance, Faculty of Business Studies \\ University of Dhaka, Dhaka-1000, Bangladesh \\ E-mail: miaduddinf@gmail.com
}

\begin{abstract}
For determining the expected return, and asset pricing, CAPM (Capital asset pricing model) is being used dominantly grounded on only the market (systematic) risk-factor though several anomalies have been revealed in this model. Fama and French (1993) have addressed those anomalies and developed the Three-factor model by combining size and value factors besides market factors. Over time, Carhart (1997) has further developed a model addressing momentum factor besides the three factors of Fama and French (1993) which is known as the Carhart four-factor model. Though several kinds of research have been conducted on the CAPM and three-factor model, little works have been accompanied by the Carhart four-factor model in an evolving market like Bangladesh. The goal of this work is to examine the validity of the Carhart four-factor model and examine the loftier explanatory power in Dhaka Stock Exchange (DSE). From the regression analysis of the Carhart model, we have found that market, size, value, and momentum explain the excess stock return. This study indicates that the Carhart model has the lowest GRS F-statistic, highest adjusted R-squared, and lowest Sharpe ratio in contrast to the CAPM and three-factor model which indicates the superior explanatory power and statistical validity of the Carhart model.
\end{abstract}

Keywords: Carhart Four-Factor Model, Fama-French Three-Factor Model, CAPM, GRS F-Test, Dhaka Stock Exchange.

JEL Classification Codes: G12, G13, G14.

\section{INTRODUCTION}

For explaining the determinants of the excess return of expected portfolios, many researchers have come up with various assumptions and theories after the famous Modern Portfolio Theory of Markowitz (1959). The CAPM (Capital Asset Pricing Model) of Sharpe (1964) and Lintner (1964) is still being used universally for estimating the expected return because of its ease of calculation and simplicity, where the systematic risk (market) is considered as the only risk factor. Although the field 
of finance has been renovated because of this theory, the CAPM model has faced challenges from numerous empirical tests and several drawbacks have been identified. Banz (1981), Gibbons (1982), Merton (1973), and many other researchers state the misspecification of CAPM and identify other factors besides the systematic risk in their papers, for instance, size, leverage, $\mathrm{P} / \mathrm{E}$ ratio, and $\mathrm{B} / \mathrm{M}$ ratio of the firm. Among them, Bhandari (1988) find the positive effect of leverage, Stattman (1980) find the positive effect of the B/M ratio, and Basu (1977) find the effect of the P/E ratio on the expected return of the stock in the US Market. Besides, a robust role of the B/M ratio is found in the Japanese market by Chan, Hamao, and Lakonishok (1991). But all of these researches can't address strong specific factors to explain excess returns.

Then, the Fama-French three-factor model was established regarding the drawbacks of CAPM, where they consider the systematic risk (market) along with size and value to interpret the expected portfolio return (Fama \& French, 1992). They form portfolios for stocks for mimicking the risk factors and relate the size and $\mathrm{B} / \mathrm{M}$ ratio which capture significant common stock return variations regardless of the time-series regression along with presenting the evidence that size and $\mathrm{B} / \mathrm{M}$ work as a proxy to measure the sensitivity of common stock risk factors. Jegadeesh and Titman (1993) originate the momentum strategy which has been re-examined by Carhart (1997), where he considers the short-term momentum as another factor besides the three factors of the Fama-French model, which is widely known as the "Carhart Four-Factor Model". Carhart (1997) argues that the oddities related to the FamaFrench and CAPM models are better captured by the Carhart model. Jegadeesh and Titman (1993) state the strategies of buying those stocks having well performance and selling those stocks having poor performance in the past, generate remarkable favorable returns for holding period over short-term (3-12 months) and these strategies are not for systematic risk rather it is the part of the abnormal returns of portfolio formation and also have documented an alike form of returns for past winners and losers. Carhart (1997) illustrates that the individual stock return can be described by $4.6 \%$ out of $8 \%$ by size and momentum strategy and considers the short-term momentum strategy as more explanatory than long-term momentum strategy (2-5 years).

Most of the research related to the Carhart model is conducted in developed markets whereas developing markets like Bangladesh remained less explored. But the significance of the CAPM and the Fama-French model along with other factors are examined in Bangladesh (Hasan et al., 2015; Mobarek \& Mollah, 2005; Rahman, Baten, \& Alam, 2006). Mobarek and Mollah (2005) conduct the empirical analysis on DSE and find that market factors cannot explain stock return. Rather, other variables including size, earnings yield, price to book, share volume, and cash flow yield can explain the share returns significantly where the consistency of the degree of a relationship has been found with an emerging market (Mobarek \& Mollah, 2005). Rahman, Baten, and Alam (2006) conduct the study of the CAPM model and the three-factor model for 1999 to 2003 in Bangladesh and find the linear and favorable relationship between stock and market return. Hasan et al. (2015) study the stock returns in DSE by using the Fama-French methodology and find that the model is appropriate in DSE with high $\mathrm{R}$-squared and they find that small size firms having low B/M produce a greater mean monthly return than big size firms having low B/M. The empirical evidence indicates that though the significance of the CAPM and the Fama-French model are examined in Bangladesh, the application of the Carhart model is still in the demonstrating phase. The goal of this study is to identify the determinants of expected return by examining the validity and superiority of the Carhart four-factor model by applying the model to the listed companies in Dhaka Stock Exchange, Bangladesh to explain the excess stock return. 


\section{LITERATURE REVIEW}

During the evolution of the Modern Portfolio Theory of Markowitz (1959), academicians and researchers have been entailed in the analysis and discussion of risk-return characteristics, optimum portfolio, and risk minimization. The cross-sectional analysis of expected returns of stocks is being considered as one of the leading research areas in finance for nearly six decades. There has been a long debate in determining the factors of stock return in the literature of asset pricing. Undoubtedly, the famous model of asset pricing by Sharpe (1964) and Lintner (1965), known as the capital asset pricing model (CAPM), has reshaped the thinking of researchers in determining the factors of average riskreturn. They improve the model of Markowitz (1959) by involving the risk-free asset in the model. Besides, Sharpe (1964) and Lintner (1965) set an assumption that an investor can involve in selling and buying at a constant rate without any limit. A distinctive point is provided by CAPM in the concept of an efficient portfolio, where Sharpe (1964) and Lintner (1965) derive numerous sets of efficient portfolios. These portfolios combine risk-free assets and a single portfolio. Then, the market return has been identified as the only risk factor of the stock's expected return in CAPM. CAPM has worked as the first framework where it described how the investment risk should affect its expected return. CAPM also argues that risk is diversifiable by holding other investments in the portfolio. Besides, based on the efficient-market portfolio, a positive straight-line relationship exists between the securities' expected return and the systematic factor (market) of those securities, which describes the cross-sectional expected return.

Though the CAPM model is mathematically simple and sound in the implication, a full explanation of asset returns against past returns cannot be explained by it. Different researchers have tried to enhance the elucidatory power of this model over time by adding various assumptions, variables, or by applying different methodologies. All of these works have given some remarkable insights and explanations about market factors and to meet the loopholes of the CAPM model. Thus, different researchers attempt to use different proxy variables of various factors for explaining the riskreturn relationship for assets. Merton (1973) finds that there exists a distinction between the expected returns on risky assets and the risk-free rate. This difference also exists even when they have no systematic risk. Banz (1981) states the misspecification of CAPM and indicates other factors through which an asset's cross-sectional average return can be explained. Banz (1981) finds the existence of a strong size effect in the cross-sectional average returns of the US market for at least 40 years, but he does not find the reason for this size effect. Moreover, he finds that small size stocks experience greater average returns and big size stocks experience lower average returns given their beta estimates (Banz, 1981). Gibbons (1982) finds that the practical content of the CAPM is rejected with a significance level of less than $1 \%$ when he takes the market beta for explaining cross-sectional average returns on US stocks from 1926-1975. Bhandari (1988) states the positive relation between leverage and mean return when he identifies a dissimilarity with the CAPM model. Leverage risk including size and beta can illustrate the average returns of stocks (Bhandari, 1988). Stattman (1980) finds the existence of a positive relationship between the $\mathrm{B} / \mathrm{M}$ ratio and average returns on U.S. stocks, which is similar to the statement of Rosenberg and Reid (1985). Later, Chan, Hamao, and Lakonishok (1991) take the data set of 1971-1988 on Japanese stocks and find that the B/M ratio has a significant role to explain the crosssection of mean returns. Again, Basu (1977) explains that the P/E ratio can be indicators of average returns of U.S. stocks along with the market beta and size. Ball (1978) states that the earning-price ratio is used for unnamed factors and can be lofty for stocks with greater expected returns and risk. All of these researches predict that there has a relationship of mean stock return with $\mathrm{B} / \mathrm{M}$ ratio, size, $\mathrm{C} / \mathrm{P}$ ratio, and $\mathrm{P} / \mathrm{E}$ ratio. 
Later, Fama and French (1992) state some straightforward results whatever be the underlying economic causes for the time frame of 1963-1990. They state that size and B/M are two easily measured variables that provide a powerful and simple depiction of a cross-section of average stock returns. They also state that during the sample period of 1963-1990, market beta cannot fully illustrate the cross-section of average stock returns. But the combined effects of the B/M ratio and the size of firms can occupy the impact of leverage and E/P (Fama \& French, 1992). Further, Fama and French (1993) investigate the frequently considered risk factors in the return on stocks and bonds where five common risk factors are identified. Market factor, firm size, and B/M equity are usual risk factors of the stock market whereas, maturity and default risk factors are usual risk factors of the bond market (Fama \& French, 1993). They construct portfolios for stocks for mimicking the risk factors and relate the size and $\mathrm{B} / \mathrm{M}$ ratio which have captured significant common return variations regardless of the time-series regression along with presenting the evidence that size and $\mathrm{B} / \mathrm{M}$ ratio can be proxy for measuring the responsiveness of common risk factors. Fama and French (1992) also evaluate the intercepts from three-factor regressions including the excess market return and the imitating returns for size and $\mathrm{B} / \mathrm{M}$ factors close to 0 . This model is known as the famous Fama-French three-factor model. In this model, market, size, and $\mathrm{B} / \mathrm{M}$ ratio (value) factors are considered as proxies for risk factors to examine the cross-section of mean stock returns (Fama \& French, 1992). They incorporate market premium, size premium, and value premium as predictive variables towards the excess return of a portfolio (Fama \& French, 1992).

Later, Jegadeesh and Titman (1993) present momentum as explaining variable of stock return, where they state the strategies of buying those stocks having well performance and selling those stocks having poor performance in the past, generating remarkable favorable returns for holding period over 3 to 12 months. They conclude that the likelihood of these strategies is not for their systematic risk rather it is the portion of the abnormal returns produced in the first year after portfolio formation disappears in the next two years. In the paper, they document an alike pattern of returns for past winners and losers (Jegadeesh \& Titman, 1993). Carhart (1997) re-examines the momentum strategy outlined by Jegadeesh and Titman (1993) for the period of 1962-1993 and proposes to add this momentum factor with the three-factor model of Fama-French. Carhart (1997) states that the stock return can be illustrated by $4.6 \%$ out of $8 \%$ by size and momentum strategy. Besides, short-term momentum strategy is considered to have more explanatory power than long-term momentum strategy (2-5 years) which is also consistent with Jegadeesh and Titman (1993). Thus, in the Carhart model, short-term momentum is also outlined as another factor along with the three factors of Fama and French (1992) (market, size, and value factors). In response to the Carhart model, Fama and French (2012) further examine the fourfactor model after adjusting momentum in 2012. They apply the model in 23 developed countries from 1989 to 2011 and divide those into 4 regions (Europe, North America, Asia, and Japan). They explain the mean return by using various strategies, such as value, size, and momentum, in developed countries and find that except in japan, momentum, and value premium exist everywhere (Fama \& French, 2012).

The power of the Carhart model in the Japanese stock market for 1984-2009 has been examined by Bretschger and Lechthaler (2012) and they find that the Carhart model has been performed well to describe the stock returns. Nwani (2015) finds notable evolutionary power of both the three-factor and four-factor model on the London stock exchange for 1996-2003 (except size effect). Artmann, Finter, and Kempf (2006) also find that the Carhart model has performed superior to the Fama-French model in the German stock market from 1963 to 2006. Other researchers such as Ammann and Steiner (2008); Czapkiewicz and Wójtowicz (2014) in Poland apply the Carhart model and find the robustness of the 
model. The above empirical evidence picture that the four-factor model provides superior performance to explain returns of stock than the three-factor model.

In Dhaka Stock Exchange (DSE), the researchers find mixed nature in the power of variables for explaining the returns of stocks. Mobarek and Mollah (2005) conduct the empirical analysis on DSE and find no favorable relationship between market beta and share return which has been described by the CAPM model. Rather, they find that other variables including size, earnings yield, price to book, share volume, and cash flow yield can explain the share returns significantly where the consistency of the degree of a relationship has been found with an emerging market (Mobarek \& Mollah, 2005). Later, Chowdhury and Sharmin (2013) find that only the market returns can explain the returns of stock where they state the negative relationship between stock and market return. They also find that the P/E ratio, size, liquidity, and dividend yield have no explanatory power on the stock returns and this result was contradictory to Mobarek and Mollah (2005). Rahman, Baten, and Alam (2006) conduct the study of the CAPM model for 1999 to 2003 and find the linear and favorable relationship between stock and market return. Hasan et al. (2015) study the size and value effect on stock returns in DSE by using the Fama-French methodology and find the appropriateness of the model in DSE with high R-squared and also find that small-sized firms with low B/M produce a greater mean monthly return than large-sized firms with low B/M. The above empirical evidence indicates that various research works have been done on the CAPM and Fama-French model along with examining other variables in DSE. But the effect of the momentum factor on stock returns remains almost unexamined. The motive of this research paper is to validate and test the superiority of the Carhart Four-Factor model to describe the determinants of expected stock returns in DSE.

\section{DATA AND RESEARCH METHODOLOGY}

This study is stringently quantitative in nature. The required data is obtained from DSE (Dhaka Stock Exchange) and Datastream. Analysis has been conducted using Stata software. The multiple regression model is used for conducting the validity test and the effectiveness of the Carhart model. Adjusted RSquared has been examined as a validity of the regression output. When we use multiple independent variables in the analysis, the R-squared is inflated in the computation process. Thus, the Adjusted RSquared can provide better results in multiple regression analysis by eliminating the inflationary results of R-Squared. The statistical significance of the intercepts can be measured through GRS F-statistic and p-value and the model can be measured through F-statistic. The short-term anomalies have been reduced by using the 10 -year time frame for the dataset.

\section{Data}

For the study purpose, we have collected the monthly data of the adjusted closing stock price, total stock return, and market capitalization of the selected company of the Dhaka Stock Exchange from Datastream for a period of 11 years (January 2009 to December 2019). The 11 years of trading data availability and other fundamental screening measures like net asset value (NAV) per share, stock market index have been collected from the DSE library and DSE websites. We have collected monthly data of the three-month treasury rate of Bangladesh from Datastream. The selection of stocks is based on the assumptions of the Fama-French model. Thus, we exclude financial institutions (both banks and non-bank) from the sample as the asset-liability structure of these institutions comprises high financial leverage and this structure obstructs the comparability of the $\mathrm{B} / \mathrm{M}$ ratio with other non-financial institutions. The excluded bank and non-bank financial stocks include the following sectors: bank, financial institutions, debenture, insurance, mutual fund, and treasury bond. Besides, some inactive stocks are also excluded based on their trading activity and the availability of data. We exclude stock 
with negative book-market ratios following Fama and French $(1996,2012)$ methodology. Further, we have winsorized stock returns at the $1^{\text {st }}$ and $99^{\text {th }}$ percentile to address outliers that are widely used in the literature (Berger \& Bouwman, 2009; Dixon, 1960). Based on the above assumptions and criteria, ultimately 85 companies have been selected as a sample for this study. Among the collected 11 years data, the 10 years from 2010 to 2019 are used to run the regressions and 2009 data is used to calculate the momentum for the year 2010. In total, 8,704 monthly observations for the period from 2010 to 2019 have been used to run regressions.

\section{Proxy of Market Portfolio}

For the proxy of the market return, we have collected the Dhaka Stock Exchange General Index (DGEN) and DSE Broad Index (DSEX) from the DSE library. DSE introduced DSEX on January 28, 2013, as a broad market index. So, for the market return calculation, we have used DGEN data from 2009 to 2012 and DSEX data from 2013-2019.

The formula used to calculate market return in this study for month $t$ is as follows:

$R m_{t}=\frac{M I_{t}-M I_{t-1}}{M I_{t-1}}$

Where,

$$
\begin{aligned}
& R m_{t}=\text { Total market return in month } t \\
& M I_{t}=\text { Market Index in month } t \\
& M I_{t-1}=\text { Market Index in month } t-1
\end{aligned}
$$

\section{Risk-Free Interest Rate}

We have taken the three-month treasury bill rate of the Bangladesh government as a risk-free rate. Monthly data of the three-month treasury bill has been obtained from Datastream.

\section{Excess Stock Return Calculation}

Monthly total stock returns have been used for 11 years. Monthly total stock returns have been obtained from Datastream. Both the capital gain and adjustment for cash or stock dividends and stock splits have been considered for the calculation of total stock return. Datastream uses adjusted closing stock prices to calculate total stock return. Adjusted closing stock prices of Datastream are adjusted for stock dividends, stock splits, and many other corporate actions to make every price comparable over time. The formula used to calculate total stock return in this study for stock $i$ in month $t$ is:

$R_{i, t}=\frac{P_{i, t}+\operatorname{Cash}^{D i v_{i, t}-P_{i, t-1}}}{P_{i, t-1}}$

Where,

$$
\begin{aligned}
& \mathrm{R}_{\mathrm{i}, \mathrm{t}}=\text { Total return of stock } i \text { in month } \mathrm{t} \\
& \mathrm{P}_{\mathrm{i}, \mathrm{t}}=\text { Adjusted closing price of stock } i \text { in month } \mathrm{t} \\
& \mathrm{P}_{\mathrm{i}, \mathrm{t}-1}=\text { Adjusted closing price of stock } i \text { in month } \mathrm{t}-1 \\
& \text { Cash Div } \mathrm{D}_{\mathrm{i}, \mathrm{t}}=\text { Cash dividend per share of stock } i \text { in month } \mathrm{t}
\end{aligned}
$$

The risk-free rate of month $t\left(R f_{t}\right)$ is subtracted from the total return of each stock $\left(R_{i, t}\right)$ for calculating the excess stock return $\left(R_{i, t}-R f_{t}\right)$. 


\section{Regression Model and Variable}

To conduct the empirical tests of the asset pricing model, it requires to specify the risk factors which work as explanatory variables and assets which work as dependent variables. These risk factors and assets are used in the multiple regressions. Thus, for generating these explanatory and dependent variables, portfolio formulation is conducted. The four-factor model (Carhart model) involves estimating the following regression:

$R_{i, t}-R f_{t}=\alpha_{i}+b_{i}\left\lfloor R m_{t}-R f_{t}\right\rfloor+s_{i} S M B_{t}+h_{i} H M L_{t}+w_{i} W M L_{t}+e_{i t}$

The right-hand side (RHS) of the equation refers to the explanatory variables of portfolio formation known as RHS portfolios and the left-hand side (LHS) of the equation refers to the dependent variables of portfolio formation known as LHS portfolios.

In the regression model,

$R_{i, t}$ refers the total return on asset $i$ of month $t$

$R f_{t}$ refers the risk-free rate of month $t$

$R m_{t}$ refers the market return of month $t$

$R m_{t}-R f_{t}$ refers the market risk premium of month $t$

$S M B_{t}$ refers to the gap between the mean return of small-cap stocks and big-cap stocks on diversified portfolios of month $t$, known as size premium

$H M L_{t}$ refers to the gap between the mean return of value stocks having high $\mathrm{B} / \mathrm{M}$ and growth stocks having low $\mathrm{B} / \mathrm{M}$ on diversified portfolios of month $t$, known as the value premium

$W M L_{t}$ refers the momentum factor premium of month $t$

$b_{i}, s_{i}, h_{i}$ and $w_{i}$ are the coefficients of the market, size, value, and momentum factors, respectively.

\section{Portfolio Construction}

To obtain the explanatory variables of the regression, portfolios are formed by mimicking the portfolio approach of the Fama-French model and the Carhart Model. Portfolios are constructed based on the size-B/M ratio, and the size-momentum. Excess stock returns are used to calculate all the portfolios' returns.

\section{Size and Value Portfolios}

Market capitalization is employed to measure the size of the firm. The book value of equity is outlined as the gap between year-end total assets and total liabilities. For convenience, NAV (Net Assets Value) per share is used as the proxy for the book value of equity. The book-to-market ratio (B/M) is calculated at the year-end for each selected company where NAV per share of a company is divided by the year-end market capitalization per share of the company. In consistent with the three-factor model, stocks having negative $\mathrm{B} / \mathrm{M}$ ratios are excluded.

RHS (Right Hand Side) portfolios are constructed from $2 \times 3$ types based on size and B/M to calculate the explanatory returns. Portfolios are constructed at the end of December of the year $t$. The equal-weighted monthly stock return of each portfolio is determined from January of year $t+1$ to December of year $t+1$; further, these portfolios are reconstructed in December of year $t+1$. In the RSH portfolios, stocks are assembled under two portfolios according to the size where the threshold level is the central point (median) of market capitalization. Those stocks are further assembled into 3 portfolios according to the $\mathrm{B} / \mathrm{M}$ ratio. Two percentiles $\left(30^{\text {th }}\right.$ and $\left.70^{\text {th }}\right)$ of the $\mathrm{B} / \mathrm{M}$ ratio are taken as the breakpoints for these three portfolios. There have been produced 6 portfolios from the convergence of 
the independent $2 \times 3$ grades on size and $\mathrm{B} / \mathrm{M}$ ratio. These are $\mathrm{SG}, \mathrm{BG}, \mathrm{SN}, \mathrm{BN}, \mathrm{SV}$, and $\mathrm{BV}$ respectively (here, $\mathrm{S}=$ Small, $\mathrm{B}=\mathrm{Big}, \mathrm{G}=$ Growth, $\mathrm{N}=$ Neutral and $\mathrm{V}=$ Value). The market capitalizations of small firms are below the median value and big firms remain above the median value. Having a $\mathrm{B} / \mathrm{M}$ ratio of lower than $30^{\text {th }}$ percentile are growth firms and greater than $70^{\text {th }}$ percentile are value firms and neutral firms lie between $30^{\text {th }}$ and $70^{\text {th }}$ percentiles. By definition, the monthly size premium or size factor (SMB) can be addressed out as the gap of the average return of the portfolios on the 3 small-cap and the 3 big-cap. Again, HML (monthly) can be addressed as the gap of the average return of the portfolios on the 2 high $\mathrm{B} / \mathrm{M}$ and 2 low B/M. To develop the return outcomes as dependent variables for the regression, LHS portfolios are generated. The LHS portfolios apply $3 \times 3$ grades on size and B/M ratio. Eventually, that brings out 9 other portfolios.

\section{Size and Momentum Portfolios}

For calculating the monthly momentum factor (WML), the lagged return is used. Thus, another $2 \times 3$ sorts of portfolios are generated on size and lagged return. We construct yearly size-momentum portfolios and returns of the portfolios are determined for the following year. Such as the momentum of the financial year 2010 is calculated by comparing the data with the financial year 2009. The remaining methodologies for portfolio formation follow the same. Therefore, there have been 6 portfolios from the convergence of the independent $2 \times 3$ grades on size and lagged returns. These are SL, BL, SN, BN, $\mathrm{SW}$, and $\mathrm{BW}$ respectively (here, $\mathrm{S}=\mathrm{Small}, \mathrm{B}=\mathrm{Big}, \mathrm{W}=$ Winners, $\mathrm{N}=$ Neutral, and L=Losers). Firms that have lagged returns under the $30^{\text {th }}$ percentile are considered as losers, firms that have lagged returns above the $70^{\text {th }}$ percentile are considered as winners and neutral firms lie between $30^{\text {th }}$ and $70^{\text {th }}$ percentiles. By definition, the monthly momentum premium (WML) can be addressed out as the gap between the average return of the 2 winners' portfolios and the 2 losers' portfolios. To develop the return outcomes as dependent variables for the regression, LHS portfolios are generated. The LHS portfolios apply $3 \times 3$ grades on size and momentum. Eventually, that brings out 9 other portfolios.

\section{Statistical Methods}

To assess the ability of the CAPM, Fama-French model, and Carhart model to explain the variation of cross-sectional excess returns in the DSE, the GRS F-statistic along with its p-value, average absolute intercept, adjusted R-squared, standard error of the intercepts, and Sharpe ratio of the intercepts are analyzed. The GRS F-statistic tests whether the regression intercept statistically deviates from zero or not (Gibbons, Ross, \& Shanken, 1989). Sharpe ratio indicates the mean returns of a model that remains unexplained (Fama \& French, 2012). A model with a lower Sharpe ratio is better. Adjusted R-squared measures the explanatory power of the model.

\section{Descriptive Statistics}

\section{DISCUSSION OF RESULTS}

Table 1 represents the summary statistics of variables over the selected sample period. It includes the mean monthly returns along with standard deviation, maximum and minimum value of selected stocks excess return $\left(R_{i}-R f\right)$, excess market return $(m-R f)$, SMB, HML, and WML.

Table 1. Summary statistics

\begin{tabular}{|l|l|l|l|l|l|}
\hline Variable & Mean & Std. Dev. & Min & Max & Observations \\
\hline$R_{i, t}-R f_{t}$ & -0.0431 & 0.1468 & -0.4232 & 0.6216 & 8,704 \\
\hline$R m_{t}-R f_{t}$ & -0.0526 & 0.0772 & -0.3559 & 0.1669 & 120 \\
\hline
\end{tabular}




\begin{tabular}{|l|l|l|l|l|l|}
\hline$S M B_{t}$ & 0.0024 & 0.0121 & -0.0332 & 0.0642 & 120 \\
\hline$H M L_{t}$ & 0.0010 & 0.0127 & -0.0297 & 0.0392 & 120 \\
\hline$W M L_{t}$ & 0.0066 & 0.0393 & -0.1369 & 0.1785 & 120 \\
\hline
\end{tabular}

On average, the monthly excess stock return is $-4.31 \%$. The monthly excess market return is negative $(-5.26 \%)$ which represents the overall downtrends of the market (DSE). The table also shows the mean return from SMB, HML, and WML are $0.24 \%, 0.10 \%$ and $0.66 \%$ respectively. The positive mean of SMB, HML, and WML represents the strong evidence of size, value, and momentum effect in DSE. The excess market return has experienced the maximum standard deviation $(7.72 \%)$.

\section{Correlation Matrix}

Table 2 represents the correlation matrix of the variables. The correlation coefficients of excess stock return with market, size, value, and momentum factors are 0.49, 0.25, 0.04, and 0.09, respectively.

Table 2. Correlation matrix

\begin{tabular}{|l|l|l|l|l|l|}
\hline & 1 & 2 & 3 & 4 & 5 \\
\hline $1 R_{i, t}-R f_{t}$ & 1.00 & & & & \\
\hline $2 R m_{t}-R f_{t}$ & 0.49 & 1.00 & & & \\
\hline $3 S M B_{t}$ & 0.25 & 0.05 & 1.00 & & \\
\hline $4 H M L_{t}$ & 0.04 & 0.04 & -0.05 & 1.00 & \\
\hline $5 W M L_{t}$ & 0.09 & 0.08 & -0.25 & 0.65 & 1.00 \\
\hline
\end{tabular}

\section{Size-B/M Portfolios}

The SMB is estimated as the gap of the mean excess return of 3 small-cap and the 3 big-cap portfolios. Again, the HML is estimated as the gap of the mean excess return of the portfolios on the 2 high $\mathrm{B} / \mathrm{M}$ and 2 low B/M. To develop the return outcomes as dependent variables for the regression, LHS portfolios are generated. The LHS portfolio applies $3 \times 3$ grades on size and B/M ratio. Eventually, that brings out 9 other portfolios. The average excess returns and standard deviation of these 9 size-B/M portfolios are reported in Table3. Here size is ranked from smallest to largest market capitalization and indicated by numbers 1,2 , and 3 , respectively, and $\mathrm{B} / \mathrm{M}$ equity is ranked from lowest to highest by numbers 1,2 , and 3 , respectively.

Table 3. Results of the mean excess return of 9 size-B/M portfolios

\begin{tabular}{|l|l|l|l|l|l|l|l|l|}
\hline \multicolumn{7}{|c|}{ B/M Equity } \\
\hline \multirow{2}{*}{ Size } & 1 & 2 & 3 & & 1 & 2 & 3 \\
\cline { 2 - 8 } & \multicolumn{2}{|l|}{ Mean Excess Return } & \multicolumn{4}{|c|}{ Standard Deviation } \\
\hline 1 & -0.0340 & -0.0369 & -0.0185 & 1 & 0.1780 & 0.1556 & 0.1864 \\
\hline 2 & -0.0507 & -0.0487 & -0.0499 & 2 & 0.1337 & 0.1478 & 0.1341 \\
\hline 3 & -0.0555 & -0.0490 & -0.0466 & 3 & 0.1340 & 0.1259 & 0.1056 \\
\hline
\end{tabular}

Table 3 shows that the persistent pattern of standard size effect has been observed in the portfolios as the smaller firms have a larger average return (as the less negative returns) than the larger firms such as $-3.40 \%,-5.07 \%$, and $-5.55 \%$ respectively for the growth portfolios based on sizes and this 
consistency of size effects also holds for neutral and value portfolios. Thus, the size pattern to be seen in all the value groups. Again, it shows that the persistent pattern of standard value effect has been observed in the portfolios as value firms experience higher excess return (lower negative return) than growth firms, such as $-3.40 \%,-3.69 \%$, and $-1.85 \%$ for respectively for the small size company based on value factors and it remains consistent for the rest of the portfolios. Thus, the value patterns are observed in all the size groups. The small-cap stocks have the highest average returns of $1.55 \%$ for the spread in value versus growth. The big-cap stocks have average returns of $0.89 \%$ for the spread in value versus growth. The findings are compatible with the research of the Fama-French model (1992, 2012) and Mobarek and Mollah (2015). Along with that, we find consistency with Hasan et al. (2015) where the appropriateness of the three-factor model in DSE is examined and observe that small-size firms with low $\mathrm{B} / \mathrm{M}$ produce a higher return.

\section{Size-Momentum Portfolios}

The WML (momentum premium) is addressed out as the gap of the mean excess return of 2 winners' portfolios and 2 losers' portfolios. To develop the return outcomes as dependent variables for the regression, LHS portfolios are generated. The LHS portfolio applies $3 \times 3$ sorts on size and momentum. Eventually, that brings out 9 other portfolios. The mean excess returns and standard deviation of these 9 size-momentum portfolios are presented in Table 4. Here size is ranked from smallest to largest market capitalization and indicated by number 1,2,3, and momentum is ranked from losers to winners by number 1,2,3 respectively.

Table 4. Results of mean excess return for the 9 size-momentum portfolios

\begin{tabular}{|l|l|l|l|l|l|l|l|}
\hline \multicolumn{7}{|c|}{ Momentum } \\
\hline \multirow{2}{*}{ Size } & 1 & 2 & 3 & & 1 & 2 & 3 \\
\cline { 2 - 8 } & \multicolumn{2}{|c|}{ Mean Excess Return } & \multicolumn{4}{|c|}{ Standard Deviation } \\
\hline 1 & -0.0573 & -0.0209 & 0.0029 & 1 & 0.1590 & 0.1603 & 0.2026 \\
\hline 2 & -0.0733 & -0.0393 & -0.0391 & 2 & 0.1438 & 0.1146 & 0.1521 \\
\hline 3 & -0.0718 & -0.0440 & -0.0401 & 3 & 0.1144 & 0.1012 & 0.1412 \\
\hline
\end{tabular}

Table 4 shows that the momentum pattern exists in the small-cap stocks. When we move from left to right, we find an increasing pattern in the average return, explaining that last year's winner firms have greater returns than loser firms. Such as, SW (small-winner) portfolio has the maximum average excess return of $0.29 \%$ than the SL (small-losers) portfolio of $-5.73 \%$. The spread of momentum excess return (excess returns of winners minus the excess return of losers) is higher in the small-cap stocks $(6.02 \%)$ than that of the big-cap stocks $(3.17 \%)$. Table 4 also reports that the standard deviations of the small-cap momentum portfolios are higher than the big-cap momentum portfolios. These findings are compatible with the research of Fama and French (2012).

\section{Asset Pricing Tests}

\section{Size-B/M Portfolios}

The regressions of the Carhart model are used for explaining the excess returns on portfolios that have been formed on independent size-B/M equity and size-momentum portfolios. 
Table 5. Carhart model regression analysis on 9 size-B/M portfolios

\begin{tabular}{|c|c|c|c|c|c|c|c|}
\hline \multicolumn{8}{|c|}{ B/M Equity } \\
\hline \multirow[t]{3}{*}{ Size } & 1 & 2 & 3 & & 1 & 2 & 3 \\
\hline & \multicolumn{7}{|c|}{$R_{i t}-R f_{t}=\alpha_{i}+b_{i}\left\lfloor R m_{t}-R f_{t}\right\rfloor+s_{i} S M B_{t}+h_{i} H M L_{t}+w_{i} W M L_{t}+e_{i t}$} \\
\hline & \multicolumn{3}{|c|}{$a_{i}$} & & \multicolumn{3}{|c|}{ t-statistic } \\
\hline 1 & -0.00 & $-0.01 * *$ & -0.01 & 1 & -0.73 & -2.40 & -1.22 \\
\hline 2 & -0.00 & -0.00 & $-0.01 * *$ & 2 & -0.94 & -0.11 & -2.54 \\
\hline \multirow[t]{2}{*}{3} & 0.00 & 0.00 & $-0.01 * *$ & 3 & 0.90 & 0.35 & -2.48 \\
\hline & \multicolumn{3}{|c|}{$b_{i}$} & & \multicolumn{3}{|l|}{ t-statistic } \\
\hline 1 & $0.86 * * *$ & $0.85 * * *$ & $0.76 * * *$ & 1 & 16.11 & 11.73 & 12.78 \\
\hline 2 & $1.16 * * *$ & $1.07 * * *$ & $0.89 * * *$ & 2 & 20.88 & 19.23 & 18.48 \\
\hline \multirow[t]{2}{*}{3} & $1.10 * * *$ & $0.97 * * *$ & $0.73 * * *$ & 3 & 21.25 & 22.35 & 21.09 \\
\hline & \multicolumn{3}{|c|}{$s_{i}$} & & \multicolumn{3}{|l|}{ t-statistic } \\
\hline 1 & $6.51 * * *$ & $7.42 * * *$ & $4.94 * * *$ & 1 & 18.06 & 14.24 & 14.31 \\
\hline 2 & $3.97 * * *$ & $3.48 * * *$ & $1.23 * * *$ & 2 & 9.57 & 9.41 & 4.03 \\
\hline \multirow[t]{2}{*}{3} & $1.66 * * *$ & -0.30 & -0.33 & 3 & 3.86 & -1.04 & -1.42 \\
\hline & \multicolumn{3}{|c|}{$h_{i}$} & & \multicolumn{3}{|l|}{ t-statistic } \\
\hline 1 & $-4.31 * * *$ & -0.89 & $1.47 * * *$ & 1 & -9.76 & -1.62 & 2.94 \\
\hline 2 & $-1.52 * * *$ & $-1.60 * * *$ & 0.27 & 2 & -3.59 & -3.69 & 0.68 \\
\hline \multirow[t]{2}{*}{3} & $-2.18 * * *$ & 0.03 & $1.56 * * *$ & 3 & -4.58 & 0.08 & 5.35 \\
\hline & \multicolumn{3}{|c|}{$w_{i}$} & & \multicolumn{3}{|l|}{ t-statistic } \\
\hline 1 & $1.25 * * *$ & $1.23 * * *$ & $0.47 * * *$ & 1 & 8.27 & 6.30 & 2.83 \\
\hline 2 & $0.90 * * *$ & $0.70 * * *$ & $0.31 * *$ & 2 & 6.06 & 4.44 & 2.31 \\
\hline \multirow[t]{2}{*}{3} & $0.92 * * *$ & $0.31 * * *$ & 0.04 & 3 & 6.39 & 2.72 & 0.45 \\
\hline & \multicolumn{3}{|c|}{ Adjusted R-squared } & & \multicolumn{3}{|l|}{ F-statistic } \\
\hline 1 & 0.37 & 0.30 & 0.43 & 1 & $181.49 * * *$ & $85.31 * * *$ & $166.76^{* * *}$ \\
\hline 2 & 0.36 & 0.33 & 0.33 & 2 & $140.95 * * *$ & $125.85 * * *$ & $113.34 * * *$ \\
\hline 3 & 0.47 & 0.33 & 0.34 & 3 & $144.29 * * *$ & $140.49 * * *$ & $146.76^{* * *}$ \\
\hline
\end{tabular}

$*, * *$ and $* * *$ represents statistical significance at $10 \%, 5 \%$ and $1 \%$ level of significance, respectively.

Table 5 reports the Carhart four-factor model regression results of the 9 size-B/M portfolios. The intercepts $\left(a_{i}\right)$, the coefficients of the market $\left(b_{i}\right)$, size $\left(s_{i}\right)$, value $\left(h_{i}\right)$, momentum $\left(w_{i}\right)$ factors and their respective t-statistics, adjusted R-squared, and F-statistic are presented for each regression. Size in Table 5 is categorized as small-cap, medium-cap, and large-cap portfolios and indicated by 1, 2, and 3 respectively. In the same way, $\mathrm{B} / \mathrm{M}$ equity is also categorized as growth, neutral, and value portfolios and indicated by 1,2 , and 3 respectively.

The coefficient of size factor $\left(s_{i}\right)$ decreases as we move from small-cap portfolios to large-cap portfolios, such as 6.51 for SG (small-growth) portfolio and 1.66 for BG (big-growth) portfolio. The same pattern has been observed on other portfolios (neutral and value portfolios). Such as SMB $\left(s_{i}\right)$ for SV (small-value) portfolio is 4.94, whereas for BV (big-value) portfolio is -0.33 . Thus, small-cap portfolios have experienced greater excess returns than big-cap portfolios.

A value effect is found as loading on HML $\left(h_{i}\right)$ is increasing when moving from growth stocks to value stocks. Under the small size-B/M portfolios, the HML $\left(h_{i}\right)$ is -4.31 for growth portfolio, -0.89 for neutral portfolio, and 1.47 for value portfolio. Again, under the big size-B/M portfolios, the HML 
$\left(h_{i}\right)$ are $-2.18,0.03$, and 1.56 respectively for growth, neutral, and value portfolios. Thus, the value portfolios have greater excess returns than growth portfolios. These results are compatible with the findings of Fama and French (1993). In table 5, the market betas are around 1.00 in this study which is compatible with Fama and French (1993) where the market betas are closer to 1.00. In table 5, most of the coefficients of the factors and F-statistic of the models are statistically significant at a $1 \%$ level of significance but the intercepts are insignificant which indicates the validity of the Carhart four-factor model.

\section{Size-Momentum Portfolios}

Table 6 presents the Carhart model regression results of 9 size-momentum portfolios. In table 6 , the portfolios are constructed according to size and momentum. SMB $\left(s_{i}\right)$ is categorized as small-cap, medium-cap, and large-cap portfolios and indicated by 1, 2, and 3, respectively. Similarly, WML $\left(w_{i}\right)$ is categorized as losers, neutral, and winners and indicated by 1, 2, and 3, respectively. Table 6 presents that the SMB $\left(s_{i}\right)$ decreases as we move from small-cap portfolios to large-cap portfolios, such as 4.79 for SL (Small- Losers) portfolio and -1.51 for BL (Big-Losers) portfolio. The same pattern has been observed on other portfolios (neutral and winners' portfolios). Such as SMB $\left(s_{i}\right)$ for SW (SmallWinner) portfolio is 4.20 , whereas $\operatorname{SMB}\left(s_{i}\right)$ for BW (Big-Winner) portfolio is -1.71 . Therefore, the small-cap portfolios have experienced higher excess returns than big-cap portfolios.

Table 6. Carhart model regression analysis on 9 size-momentum portfolios

\begin{tabular}{|c|c|c|c|c|c|c|c|}
\hline \multicolumn{8}{|c|}{ Momentum } \\
\hline \multirow[t]{3}{*}{ Size } & 1 & 2 & 3 & & 1 & 2 & 3 \\
\hline & \multicolumn{7}{|c|}{$R_{i t}-R f_{t}=\alpha_{i}+b_{i}\left\lfloor R m_{t}-R f_{t}\right\rfloor+s_{i} S M B_{t}+h_{i} H M L_{t}+w_{i} W M L_{t}+e_{i t}$} \\
\hline & \multicolumn{3}{|c|}{$a_{i}$} & & \multicolumn{3}{|c|}{ t-statistic } \\
\hline 1 & $-0.01 * *$ & -0.01 & -0.01 & 1 & -2.15 & -1.07 & -0.92 \\
\hline 2 & 0.00 & $-0.01 *$ & $-0.02 * * *$ & 2 & 0.45 & -1.73 & -3.32 \\
\hline \multirow[t]{2}{*}{2} & $-0.01 * * *$ & $-0.01 *$ & 0.00 & 3 & -2.80 & -1.87 & 0.99 \\
\hline & \multicolumn{3}{|c|}{$b_{i}$} & & \multicolumn{3}{|c|}{ t-statistic } \\
\hline 1 & $0.37 * * *$ & $0.83 * * *$ & $0.45 * * *$ & 1 & 4.18 & 9.78 & 4.52 \\
\hline 2 & $0.45 * * *$ & $0.94 * * *$ & $0.31 * * *$ & 2 & 4.70 & 15.58 & 3.74 \\
\hline \multirow[t]{2}{*}{3} & $0.42 * * *$ & $0.79 * * *$ & $0.46 * * *$ & 3 & 4.56 & 18.28 & 7.44 \\
\hline & \multicolumn{3}{|c|}{$S_{i}$} & & \multicolumn{3}{|c|}{ t-statistic } \\
\hline 1 & $4.79 * * *$ & $6.09 * * *$ & $4.20 * * *$ & 1 & 7.71 & 11.09 & 8.73 \\
\hline 2 & 0.28 & $2.39 * * *$ & 0.34 & 2 & 0.44 & 6.39 & 0.88 \\
\hline \multirow[t]{2}{*}{3} & $-1.51 * *$ & $-0.55^{*}$ & $-1.71 * * *$ & 3 & -2.44 & -1.95 & -5.26 \\
\hline & \multicolumn{3}{|c|}{$h_{i}$} & & \multicolumn{3}{|c|}{ t-statistic } \\
\hline 1 & $-1.33 * * *$ & $-2.21 * * *$ & $-1.51 * *$ & 1 & -3.34 & -3.40 & -2.35 \\
\hline 2 & -0.42 & $-1.63 * * *$ & $-1.80 * * *$ & 2 & -1.00 & -3.84 & -4.04 \\
\hline \multirow[t]{2}{*}{3} & 0.33 & 0.45 & -0.52 & 3 & 0.82 & 1.41 & -1.32 \\
\hline & \multicolumn{3}{|c|}{$w_{i}$} & & \multicolumn{3}{|c|}{ t-statistic } \\
\hline 1 & $-0.62 * *$ & $1.54 * * *$ & $1.94 * * *$ & 1 & -2.30 & 6.33 & 7.93 \\
\hline 2 & $-1.63 * * *$ & $0.56 * * *$ & $2.46 * * *$ & 2 & -5.93 & 3.00 & 12.17 \\
\hline \multirow[t]{2}{*}{3} & $-1.26 * * *$ & 0.06 & $1.53 * * *$ & 3 & -4.67 & 0.50 & 10.45 \\
\hline & \multicolumn{3}{|c|}{ Adjusted R-squared } & & \multicolumn{3}{|c|}{ F-statistic } \\
\hline
\end{tabular}




\begin{tabular}{|l|l|l|l|l|l|l|l|}
\hline 1 & 0.36 & 0.27 & 0.41 & 1 & $180.87 * * *$ & $71.75 * * *$ & $149.78 * * *$ \\
\hline 2 & 0.40 & 0.25 & 0.40 & 2 & $152.94 * * *$ & $83.41 * * *$ & $171.57 * * *$ \\
\hline 3 & 0.29 & 0.23 & 0.52 & 3 & $74.19 * * *$ & $88.53 * * *$ & $275.94 * * *$ \\
\hline
\end{tabular}

$*, * *$ and $* * *$ represents statistical significance at $10 \%, 5 \%$ and $1 \%$ level of significance, respectively.

A momentum effect is found as loading on WML $\left(w_{i}\right)$ is increasing when moving from losers' portfolios to winners' portfolios. Under the small-momentum portfolios, the WML $\left(w_{i}\right)$ are -0.62 for losers' portfolios, -1.54 for neutral portfolios, and 1.94 for winners' portfolios. Again, under the bigmomentum portfolios, the WML $\left(w_{i}\right)$ are $-1.26,0.06$, and 1.53 , respectively for losers, neutral, and winners' portfolios. Thus, winners' portfolios have greater excess returns than losers' portfolios. In table 6, most of the coefficients of the factors and F-statistic of the models are statistically significant at a $1 \%$ level of significance but the intercepts are insignificant which indicates the validity of the Carhart four-factor model. These results are compatible with the study of Lam et al. (2010) where he applies the model on the Stock-Exchange of Hong Kong.

\section{Analysis of the validity of the Three Asset Pricing Models}

For concluding superiority among the CAPM, the Fama-French model, and the Carhart model, we have compared the key findings. The GRS F-statistic examines whether the regression intercept in the model is zero or not. So, the null hypothesis of the GRS F-statistic is:

The alternative hypothesis is:

$$
H_{0} \text { : Regression intercept is zero }
$$

\section{$H_{1}=$ Regression intercept is not zero}

Summary statistics of the regression results of three models to illustrate the returns on 9 size-B/M portfolios and 9 size-momentum portfolios are reported in Table 7 and 8, respectively. The model having low GRS F-statistic, high GRS p-value, high adjusted R-squared, low Sharpe ratio, low intercept, and high standard error of intercept is better.

Table 7. Summary statistics of regression results of three models to describe excess returns of the 9 size-B/M portfolios

\begin{tabular}{|c|c|c|c|c|c|c|}
\hline & \multicolumn{2}{|c|}{ GRS test } & \multirow{2}{*}{$\begin{array}{l}\text { Absolute } \\
\text { value of } \\
\text { Intercepts }\end{array}$} & \multirow{2}{*}{$\begin{array}{l}\text { Adjusted } \\
\text { R-squared }\end{array}$} & \multirow{2}{*}{$\begin{array}{l}\text { Standard } \\
\text { Error of } \\
\text { Intercepts }\end{array}$} & \multirow{2}{*}{$\begin{array}{l}\text { Sharpe } \\
\text { Ratio of } \\
\text { Intercepts }\end{array}$} \\
\hline & F-stat & p-value & & & & \\
\hline CAPM & 1.5401 & 0.1428 & 0.0152 & 0.5049 & 0.0116 & 0.4295 \\
\hline Fama-French Three Factor & 1.8752 & 0.0632 & 0.0079 & 0.6637 & 0.0100 & 0.4912 \\
\hline Carhart Four Factor & 1.1595 & 0.3285 & 0.0080 & 0.6992 & 0.0098 & 0.3993 \\
\hline
\end{tabular}

In Table 7, the GRS F-statistic for the regressions of 9 size-B/M portfolios of CAPM, threefactor, and four-factor models are $1.5401,1.8752$, and 1.1595, respectively and all of them have pvalue higher than 0.05 . Therefore, intercepts of all the models do not deviate from 0 (zero) at a $5 \%$ significance level. But it seems that the Carhart Four-Factor provides the lowest GRS F-statistics and highest p-value indicating the better result among the three models and the CAPM also provides better results than the Fama-French model. The Carhart model has the highest adjusted R-squared indicating that four independent variables under this model can explain more variation of the excess return of stocks in DSE than CAPM and the three-factor model. Table 7 shows that the Carhart model has the lowest Sharpe ratio of the intercepts indicating the lowest unexplained mean stock returns contrasted to 
CAPM and the three-factor model. Thus, these statistical results imply that the Carhart model captures better results (with lowest GRS F-stat, highest p-value and adjusted R-squared, and lowest Sharpe ratio) than the other two models. Whereas, the CAPM also captures better results than the Fama-French model.

Table 8. Summary statistics of regression results of three models to describe excess returns of the 9 size-momentum portfolios

\begin{tabular}{|c|c|c|c|c|c|c|}
\hline & \multicolumn{2}{|l|}{ GRS test } & \multirow{2}{*}{$\begin{array}{l}\text { Absolute } \\
\text { value of } \\
\text { Intercepts }\end{array}$} & \multirow{2}{*}{$\begin{array}{l}\text { Adjusted } \\
\text { R-squared }\end{array}$} & \multirow{2}{*}{$\begin{array}{l}\text { Standard } \\
\text { Error of } \\
\text { Intercepts }\end{array}$} & \multirow{2}{*}{$\begin{array}{l}\text { Sharpe } \\
\text { Ratio of } \\
\text { Intercepts }\end{array}$} \\
\hline & F-stat & p-value & & & & \\
\hline CAPM & 31.4922 & 0.0000 & 0.0112 & 0.4566 & 0.0126 & 2.1964 \\
\hline Fama-French Three Factor & 29.3453 & 0.0000 & 0.0110 & 0.5622 & 0.0117 & 2.2035 \\
\hline Carhart Four Factor & 23.2434 & 0.0000 & 0.0136 & 0.5901 & 0.0115 & 2.0297 \\
\hline
\end{tabular}

In Table 8, the summary statistics for regressions of the 9 size-momentum portfolios are indicating that the Carhart model is evidentially superior in contrast to the CAPM and the Fama-French model. All the results of summary statistics have improved in support of the four-factor model when we move away from the other two models and we get the lowest GRS F-statistic, highest adjusted Rsquared, and lowest Sharpe ratio in the four-factor model in comparison of other models.

Thus, the GRS F-test represents that the four-factor model is not to be rejected with regard to the DSE as it effectively captures the mean excess returns of all the size-B/M portfolios and sizemomentum portfolios. The adjusted R-square and GRS F-statistic improve when we move from CAPM to the Carhart model. Therefore, we can conclude that Carhart model is superior contrasted to CAPM and three-factor model based on lowest GRS F-statistic, highest adjusted R-squared, and lowest Sharpe ratio of intercepts which is compatible with the existing literature (Abeysekera \& Nimal, 2017; Cakici et al., 2013; Hanauer \& Linhart, 2013; Hasnaoui \& Ibrahim 2013).

\section{CONCLUSION}

The research aims to examine the validity and superiority of the Carhart four-factor model to estimate the excess return in selected securities in DSE (Dhaka Stock Exchange). Also, observing the market (systematic risk), size, value, and momentum effects on the required excess return are objectives of this research. Again, a comparison is also drawn about superior explanatory power among the CAPM, Fama-French, and Carhart Model. A 10-year time frame is selected as a dataset to do the study. The regression model has been analyzed to estimate excess stock return based on the explanatory variables (market, size, value, and momentum factors).

This study finds the existence of the above-mentioned four factors in DSE. From the regression analysis of the Carhart model, we find that market, size, value, and momentum explain the excess stock return in DSE. The lowest GRS F-statistic, Sharpe ratio, and highest adjusted R-squared represents superior explanatory power of the Carhart four-factor Model over the CAPM and Fama-French threefactor model to explain the excess return in DSE which is compatible with the existing literature (Abeysekera \& Nimal, 2017; Cakici et al., 2013; Hanauer \& Linhart, 2013; Hasnaoui \& Ibrahim 2013). This study suggests the investors of DSE to buy small-cap, high B/M stocks, and stocks that have performed well over the past twelve months. This study concludes that size, value, and momentum effects should be taken into consideration while examining the performance of portfolios in DSE. 


\section{REFERENCES}

Abeysekera, A. P., \& Nimal, P. D. (2017). The four-factor model and stock returns: evidence from Sri Lanka. Afro-Asian Journal of Finance and Accounting, 7(1), 1-15.

Ammann, M., \& Steiner, M. (2008). Risk factors for the Swiss stock market. Swiss Journal of Economics and Statistics, 144(1), 1-35.

Artmann, S., Finter, P., \& Kempf, A. (2012). Determinants of expected stock returns: large sample evidence from the German market. Journal of Business Finance \& Accounting, 39(5-6), 758784.

Ball, R. (1978). Anomalies in relationships between securities yields and yield-surrogates. Journal of Financial Economics, 6(2-3), 103-126.

Banz, R. W. (1981). The relationship between return and market value of common stocks. Journal of Financial Economics, 9(1), 3-18.

Basu, S. (1977). Investment performance of common stocks in relation to their price-earnings ratios: A test of the efficient market hypothesis. The Journal of Finance, 32(3), 663-682.

Berger, A. N., \& Bouwman, C. H. (2009). Bank liquidity creation. The Review of Financial Studies, 22(9), 3779-3837.

Bhandari, L. C. (1988). Debt/equity ratio and expected common stock returns: Empirical evidence. The Journal of Finance, 43(2), 507-528.

Bretschger, L., \& Lechthaler, F. (2012). Common risk factors and the macroeconomy: new evidence from the Japanese stock market. CER-ETH Working Paper, (12/160).

Cakici, N., Fabozzi, F.J. \& Tan, S. (2013). Size, value, and momentum in emerging market stock returns.Emerging Markets Review, 16(1), 46-65.

Carhart, M. M. (1997). On persistence in mutual fund performance. The Journal of Finance, 52(1), 5782.

Chan, L. K., Hamao, Y., \& Lakonishok, J. (1991). Fundamentals and stock returns in Japan. The Journal of Finance, 46(5), 1739-1764.

Chowdhury, S. S. H., \& Sharmin, R. (2013). Relevant factors to explain cross-section of expected returns of the firms listed in the Dhaka Stock Exchange. International Business Research, 6(3), 165.

Czapkiewicz, A., \& Wójtowicz, T. (2014). The four-factor asset pricing model on the Polish stock market. Economic research-Ekonomskaistraživanja, 27(1), 771-783.

Dixon, W.J. (1960). Simplified estimation from censored normal samples. The Annals of Mathematical Statistics, pp.385-391. 
Fama, E. F., \& French, K. R. (1992). The cross-section of expected stock returns. Journal of Finance, 47(2), 427-465.

Fama, E. F., \& French, K. R. (1993). Common risk factors in the returns on stocks and bonds. Journal of Financial Economics, 33, 3-56.

Fama, E. F., \& French, K. R. (2012). Size, value, and momentum in international stock returns. Journal of financial economics, 105(3), 457-472.

Gibbons, M. R. (1982). Multivariate tests of financial models: A new approach. Journal of Financial Economics, 10(1), 3-27.

Gibbons, M. R., Ross, S. A., \& Shanken, J. (1989). A test of the efficiency of a given portfolio. Econometrica: Journal of the Econometric Society, 1121-1152.

Hasan, M. B., Alam, M. N., Amin, M. R., \& Rahaman, M. A. (2015). The size and value effect to explain cross-section of expected stock returns in Dhaka stock exchange. International Journal of Economics and Finance, 7(1), 14-23.

Hanauer, M., \& Linhart, M. (2013). Size, Value, and Momentum in Emerging Market Stock Returns: Integrated or Segmented Pricing?. Working Paper, Technical University of Munich.

Hasnaoui, H., \& Ibrahim, F. (2013). Constructing and testing alternative versions of the Fama-French and Carhart models in Tunisia. Herald Journal of Economics and Finance, 1(1),21-34.

Jegadeesh, N., \& Titman, S. (1993). Returns to buying winners and selling losers: Implications for stock market efficiency. The Journal of Finance, 48(1), 65-91.

Lintner, J. (1965). Security prices, risk, and maximal gains from diversification. The Journal of Finance, 20(4), 587-615.

Lam, K. S., Li, F. K., \& So, S. M. (2010). On the validity of the augmented Fama and French's (1993) model: evidence from the Hong Kong stock market. Review of Quantitative Finance and Accounting, 35(1), 89-111.

Markowitz, H. (1959). Portfolio selection: Efficient Diversification of Investments. (Wiley, New York)

Merton, R. C. (1973). An intertemporal capital asset pricing model. Econometrica: Journal of the Econometric Society, 867-887.

Mobarek, A., \& Mollah, A. S. (2005). The general determinants of share returns: an empirical investigation on the Dhaka stock exchange. Review of Pacific Basin Financial Markets and Policies, 8(04), 593-612.

Nwani, C. (2015). An Empirical Investigation of Fama-French-Carhart Multifactor Model: UK Evidence. Journal of Economics and Finance, 6(1), 95-103. 
Rahman, M., Baten, M. A., \& Alam, A. (2006). An empirical testing of capital asset pricing model in Bangladesh. Journal of Applied Sciences, 6(3), 662-667.

Rosenberg, B., Reid, K., \& Lanstein, R. (1985). Persuasive evidence of market inefficiency. The Journal of Portfolio Management, 11(3), 9-16.

Sharpe, W. F. (1964). Capital asset prices: A theory of market equilibrium under conditions of risk. The Journal of Finance, 19(3), 425-442.

Stattman, D. (1980). Book values and stock returns. The Chicago MBA: A Journal of Selected Papers, 4(1), 25-45.

\section{Copyrights}

Copyright for this article is retained by the author(s), with first publication rights granted to the journal. This is an open-access article distributed under the terms and conditions of the Creative Commons Attribution license (http://creativecommons.org/licenses/by/4.0/). 